\title{
The Impact of Development Aid on the International Migrations in the African, Caribbean, and Pacific Group of States
}

\author{
Marko Gregl* \\ Klavdij Logožar **
}

\begin{abstract}
Development aid, one of the most important mechanisms for the redistribution of global wealth, represents financial flows that have economic growth and social improvement as their main objective. It has also frequently been described as an instrument which is able to diminish international migrations and is used by several developed countries. Recently, much empirical evidence and several contributors have argued that connection and set out other grounds. This paper explores the interaction between development aid and migrations from developing to developed countries. We want to determine, if the amount of development aid has any impact on migrations from African, Caribbean, and the Pacific Group of States. Our results show that development aid does not have a direct effect on migrations and therefore, in terms of international migrations, is not effective. Moreover, we will argue that the donor side should use different policies and other mechanisms to manage migrations from those countries.
\end{abstract}

Keywords: development aid; international migrations; ACP Group of States; aid effectiveness; international development

JEL Classification: F35, F22, F59

\section{Introduction}

The question of development aid and its impact on various economic and social indicators is one of the most debated topics in the field of international and development economics. Although the main reason for aid is to generate growth and development, the main global issues of less developed countries (LDC) remain unsolved. Much of the existing research shows conflicting results, and the question about the efficiency of development aid and its impact on various fields of national economies remains in dispute.

\footnotetext{
Marko Gregl, PhD Candidate, University of Maribor, Faculty of Economics and Business, Slovenia.

** Klavdij Logožar is at the University of Maribor, Faculty of Economics and Business, Maribor, Slovenia.
} 
Development aid policies face many challenges in the contemporary world. In more than 50 years of continuous cooperation, over 4.6 trillion (constant 2007) dollars (\$) have been distributed to recipient countries (Askarov and Doucouliagos 2015, 383). In spite of that, aid policies were not able to solve many global social, economic, political, and environmental issues in LDC. There are also other challenges, like the question of aid fragmentation and lack of coordination, a phenomenon of many small parts of aid coming from many donors, because development policies are increasingly proliferated. Or, the fact that aid is not distributed to the actual needs of the recipient countries, because political and strategic factors often prevail. The result of all these challenges is that the development gap between the global northern and global southern countries is not decreasing, furthermore, in the case of LDC it has remained at the same level for many years in a row. All of that and many other unsolved challenges are the major reasons why the effectiveness of development aid is seriously questioned and remains controversial.

Interest in the effectiveness and impact of foreign aid has rapidly grown in recent years. The authors mainly focus on the effect of foreign aid on economic growth. Also, it should be noted that only a limited number of studies discuss the effect of aid on other welfare indicators (Breitweiser and Wick, 2016, 554). This paper is an attempt to combine both, with the introduction of international migrations as a social and economic indicator. It studies the interaction between developmental aid and migrations from developing countries. It contributes to the literature on aid effectiveness by focusing on a specific relation between distributed development aid and international migrations in the African, Caribbean, and Pacific (ACP) group of states. There is a general consensus among international development stakeholders that fostering a country's economic development will end emigration from that state (Lacomba and Boni 2008, 138, Faini and Venturini, 1993, Gaytán-Fregoso and Lahiri 2000, 515-516). Foreign aid has been advocated as a measure that is able to reduce international migrations (Todaro and Maruszko 1987 in Gaytán-Fregoso and Lahiri 2000). As already mentioned, one of the most important missions of development aid is to generate development, which is why we are trying to determine if its amount has diminishing impact on migrations in the ACP group of states. The main hypothesis is that development aid reduces migrations abroad. If we can prove this, we might say that aid is effective.

\section{Theoretical Concepts}

\section{Development Aid}

Development aid, often also called 'Official Development Assistance' (ODA), represents one of the most important mechanisms for the redistribution of wealth in the 
world. It is a widely accepted fact that rich countries should help poor ones, and the most common way to do so is through development aid policies.

The Organization for Economic Co-operation and Development (OECD 2008) defines aid as flows to countries and territories on the Development Assistance Committee (DAC) List of ODA Recipients and to multilateral development institutions, which are:

- Provided by official agencies, including state and local governments, or by their executive agencies, and

- Each transaction, which:

a) Is administered as the promotion of economic development and welfare of developing countries as its main objective; and

b) Is concessional in character and conveys a grant element of at least 25 percent (calculated at a rate of discount of 10 percent).

Development aid may be provided for many different purposes, such as political, humanitarian, strategic, economic, and others. There are several possible channels through which aid may be distributed. The most common way is through institutions of the recipient country. It is typically used to fund expenditures that further development. Most of it is used to finance discrete investment projects building roads and schools, providing training, and education, family planning, etc. (Lancaster 1999, 490).

The debate about aid and its effectiveness is far from settled (Rajan 2005, 54). Many different types of research have been made over the years, without final and decisive results regarding development aid's positive or negative impact on donor economies. Papanek (1973 and revision 1982) was the first author to discuss positive effects of foreign aid, recently positive effects of foreign aid were supported by Burnside and Dollar (2000), Hansen and Tarp (2001), Loxley and Sackey (2008). Additionaly, there are several authors that concentrated on negative effects of development aid, e.g. Boone (1996), Kosack (2003), Easterly (2007), Easterly and Pfutze (2008), Mallik (2008).

\section{ACP Group of States}

The African, Caribbean, and Pacific (ACP) Group of States, created in the Georgetown Agreement from 1975 mainly because of partnerships with European Union member countries, is comprised of all Sub-Saharan African and most Caribbean countries, and also small islands in the Pacific. It consists of relatively big groups of states, dispersed on three different continents: Africa, Oceania, and North America. These countries hold a special status in the field of international development, due to their specific geographical and historical circumstances. Most had a common colonial history and have reached different stages of development because of specific 
political and historical reasons. On one side, there are the Sub-Saharan LDC, and on the other side there are developed economies which are located, for the most part, in the Caribbean region.

Today, the group consists of 79 members -48 from Sub-Saharan Africa, 16 from the Caribbean, and 15 from the Pacific - all of them, except Cuba, ${ }^{1}$ are signatories of the Cotonou Agreement. This is one of the most important international development documents, which defines cooperation and partnership between the group and the European Union (EU). The group is further divided into seven regional groupings: the Cariforum (Caribbean) region, ${ }^{2}$ West Africa, ${ }^{3}$ Central Africa, ${ }^{4}$ Eastern and Southern Africa (ESA), ${ }^{5}$ the East African Community (EAC), ${ }^{6}$ the Southern African Development Community (SADC), ${ }^{7}$ and the Pacific region. ${ }^{8}$

\section{International Migrations}

International migrations are both an economic and social phenomenon, closely related to globalization and income/wage gaps (Matutinović 2006, 199), with a significant impact on most of the world's economies, cultures, and other factors. It is a part of a larger process of industrialization, which has influenced national economies of the global North, as well as global southern countries. The word 'migrations' is generally used to describe the movement of people from one place to another, and international migrations usually refer to crossing national borders to settle or work in another country (Widgren and Martin 2002, 214-215). In the context of development studies this means from developing to developed countries.

Parallel with the beginnings of development aid policies, after World War II, the dynamic of advanced economies affected intense international migrations, especially from the LDC. There are many motivations for migration, beginning with economic, political, environmental, and many others like war, poverty, hunger, low wages, etc. Development seems inevitably accompanied by increasing mobility and migration. Only in the long run, after several decades of sustained growth and progressive convergence of income gaps with destination countries, does emigration tend to decrease and immigration increase (De Haas 2005).

International migrations are one of the most important contemporary issues and it is not surprising that a significant number of studies addressed this phenomenon. In his study Kandemir (2012) tried to determine main reasons for international migrations flows and suggests that most important motives for moving abroad are income, education, and health. Di Maria and Lazarova (2012) studied the correlation between skilled migration and human capital. Mergo (2016) claims that migration contributes positively to the living conditions of family members remaining behind allowing them to increase their consumption expenditure. Pecoud and de Guchteneire (2006) discussed international migrations in the context of mobility. They are in favour of 
freedom of movement and argued that strict border controls threaten democracy and have negative impact on economy and society.

\section{Literature Review}

The debate on the impact of foreign aid is a conflicting one and comes to many different conclusions. Surprisingly, previous research on the empirical impact of foreign aid on international migrations is limited. Widgren and Martin (2002) examined the impact of aid on major economic instruments: trade and investments, as well as on aid and intervention. They concluded that aid in the form of infrastructure improvements can have the short-term effect of stimulating emigration, but policies that promote trade, investment, as well as respect for human rights do not reduce emigration overnight, but are a path toward sustained reductions in migration pressure.

Belloc (2011) studied the connection between aid and migrations in 48 Sub-Saharan states and discovered that aid has a positive and statistically significant effect on aggregated migration outflows, because aid improves workers' ability to cover the costs of migration by providing new job opportunities, and in turn increasing incomes in the recipient country. Whereas, on the other hand, aid is often associated with development programs in education, communication services, and business opportunities, and may also stimulate mobility aspirations of potential migrants.

Another study was conducted by Faini and Venurini (1993). They showed that aid, which increases growth in recipient countries, would not necessarily reduce migration flows. Berthélemy, Beuran and Maurel (2009) researched if aid and migrations are substitutes or complements. They concluded that aid flows increase migration flows to donor countries below a critical income threshold in the countries of origin, rendering migration policies in donor countries more restrictive. Hatzipanayotou and Michael (2012) claim that when the donor country acts fully altruistically, and the recipient country chooses the co-financing rate optimally, then the optimal amount of aid equals the gains to the donor's welfare owing to the reduction in immigration.

Gaytán-Fregoso and Lahiri (2000) developed a two-country model with the intention of researching the correlation between aid and illegal migration. They discovered that the amount of aid is not always connected with a reduction of migrations, and that other factors must also be considered. A comprehensive study on many issues regarding migrations was made by Nyberg-Sørensen, Van Hear and Engberg-Pedersen (2002). They suggested that donor countries should revise their current approaches to selectivity in aid and focus on poverty reduction.

Blodgett Bermeo and Leblang (2015) pointed out that migration and the global allocation of foreign aid are linked and concluded that aid is being used by donor countries as part of their wider immigration strategy, seeking to foster development abroad and decrease the push factors for migration. Research by Ugarte Ontiveiros 
and Verardi (2012) suggests that good recipient-donor bilateral relations favour skilled migration and reduce migration costs for educated population. Ziesmer (2011) suggested that foreign aid given to poor countries enhances growth and reduces emigration, and that effect is greater and more significant on skilled migration than the effect on unskilled.

Many contemporary studies research links between aid and remittances, the financial flows from migrants to their home countries. Stojanov and Strielkowski (2013) found out that remittances have a stronger net positive effect on the increase of GDP per capita in developing countries than foreign aid, and De Hass (2005) suggested that migrant remittances contribute significantly to development and living conditions and that foreign aid is not a long-term solution for international migrations. Glytsos (2002) reported on beneficial and negative effects of migrant remittances on sending countries.

\section{Data and Methods}

The aim of our research is to clarify the influence of development aid on international migrations during a longer time period, namely from 1982 until 2012. The key independent variable is the amount of development aid per capita during these years. The main hypothesis of this paper is that the amount of development aid influences the reduction of migrations abroad, meaning that the higher the aid, the lower the migrations out of that country.

For the purpose of this research, we divided countries in the ACP Group of States into two groups. The first group is called 'Group A' and consists of countries, which on average received more than $\$ 100$ of development aid per capita from 1980 until 2011. The second group is called 'Group B' and includes countries, which on average received less than $\$ 100$ of development aid per capita in the same time period. The data needed to pursue our empirical research was collected from the World Bank database.

\section{Findings}

In order to link development aid with international migrations, we divided countries into two groups, as mentioned in the previous section. Due to the nature of the hypothesis, we have to exclude all of the countries in the ACP group, which had a positive net migration rate in 1982 and a few countries, for which data was unavailable. In the end, we included 11 countries from Group A, and 33 from Group B. 
Table 1: Comparison of Net Migrations in 1982 and 2012 in Group A

\begin{tabular}{|l|c|c|c|c|c|c|}
\hline \multicolumn{1}{|c|}{ Country } & $\begin{array}{c}\text { Total } \\
\text { population } \\
\mathbf{1 9 8 2}\end{array}$ & $\begin{array}{c}\text { Net } \\
\text { migration } \\
\mathbf{1 9 8 2}\end{array}$ & $\begin{array}{c}\text { \% of migr. } \\
\text { in total } \\
\text { population }\end{array}$ & $\begin{array}{c}\text { Total } \\
\text { population } \\
\mathbf{2 0 1 2}\end{array}$ & $\begin{array}{c}\text { Net } \\
\text { migration } \\
\mathbf{2 0 1 2}\end{array}$ & $\begin{array}{c}\text { \% of migr. } \\
\text { in total } \\
\text { population }\end{array}$ \\
\hline Grenada & 93,091 & -288 & -0.31 & 105,476 & $-4,274$ & -4.05 \\
\hline Guyana & 785,466 & $-84,984$ & -10.82 & 758,410 & $-32,770$ & -4.32 \\
\hline Mauritania & $1,624,310$ & $-16,100$ & -0.99 & $3,777,067$ & $-20,000$ & -0.53 \\
\hline Seychelles & 65,780 & $-3,099$ & -4.71 & 88,303 & $-1,551$ & -1.76 \\
\hline Solomon Islands & 246,502 & -1 & 0.00 & 549,162 & $-11,868$ & -2.16 \\
\hline St. Lucia & 121,150 & $-8,141$ & -6.72 & 180,890 & 40 & 0.02 \\
\hline $\begin{array}{l}\text { St. Vincent and } \\
\text { the Grenadines }\end{array}$ & 102,202 & $-7,345$ & -7.19 & 109,334 & $-5,000$ & -4.57 \\
\hline Surinam & 363,993 & $-31,771$ & -8.73 & 528,535 & $-5,000$ & -0.95 \\
\hline Tonga & 93,683 & $-12,542$ & -13.39 & 104,769 & $-8,078$ & -7.71 \\
\hline Vanuatu & 121,433 & $-3,312$ & -2.73 & 247,498 & & 0.00 \\
\hline West Samoa & 157,401 & $-17,430$ & -11.07 & 188,901 & $-12,690$ & -6.72 \\
\hline Average & $\mathbf{3 4 3 , 1 8 3}$ & $\mathbf{- 1 6 , 8 1 9}$ & $\mathbf{- 4 . 7 2}$ & $\mathbf{6 0 3 , 4 8 5}$ & $\mathbf{- 9 , 1 9 9}$ & $-\mathbf{1 . 5 2}$ \\
\hline
\end{tabular}

In Table 1 data for Group A is presented. One interesting fact is that countries in Group A almost doubled their total population in a mere 30 years, which is, especially if compared to Europe, very fast growth, and has definitely influenced migrations. ${ }^{9}$ A comparison between 1982 and 2012 reveals the following results. Countries with the highest proportion of emigrations compared to their total population in 1982 were: Tonga, West Samoa, and Guyana. Also in 2012, countries with the highest proportion of emigration were still Tonga, West Samoa, and Guyana, but all of them were able to reduce migrations. All the countries reduced migrations abroad in 30 years, but they are still above the average in the group. In 1982, the average number of migrations from countries in Group A was 16,000, and in 2012 the number was reduced to 9,000. If we take into account the fact that the overall population almost doubled, we could conclude that the number of migrations abroad significantly lowered. But only one country (Saint Lucia) was able to transform its migration rate and become a country of immigration.

The results for countries in Group B, presented in Table 2, are very similar. The only difference is that group B is, in terms of population, much larger, so we can compare results only in a proportional sense. In 1982, two countries stand out in terms of migrations abroad, which are Somalia and Antigua and Barbuda, with 13.27 and $12.82 \%$, respectively. Average migrations in that year were at $1.46 \%$, which was more than three times lower at the time, compared to Group A. All of the countries in this group reduced emigration in 2012 by almost three times, to $0.38 \%$. The average migration rate for countries was over 65,000 persons. 
Table 2: Comparison of Net Migrations in 1982 and 2012 in Group B

\begin{tabular}{|c|c|c|c|c|c|c|}
\hline Country & $\begin{array}{c}\text { Total } \\
\text { population } \\
1982\end{array}$ & $\begin{array}{c}\text { Net } \\
\text { migration } \\
1982\end{array}$ & $\begin{array}{c}\% \text { of migr. } \\
\text { in total } \\
\text { population }\end{array}$ & $\begin{array}{c}\text { Total } \\
\text { population } \\
2012 \\
\end{array}$ & $\begin{array}{c}\text { Net } \\
\text { migration } \\
2012\end{array}$ & $\begin{array}{l}\text { \% of migr. } \\
\text { in total } \\
\text { population }\end{array}$ \\
\hline $\begin{array}{l}\text { Antigua and } \\
\text { Barbuda }\end{array}$ & 68,950 & $-8,840$ & -12.82 & 89,069 & -56 & -0.06 \\
\hline Barbados & 253,836 & $-3,446$ & -1.36 & 281,580 & 1,998 & 0.71 \\
\hline Belize & 151,498 & $-5,332$ & -3.52 & 336,707 & 7,596 & 2.26 \\
\hline Benin & $3,931,355$ & $-10,848$ & -0.28 & $10,049,792$ & $-10,000$ & -0.10 \\
\hline Burkina Faso & $7,158,256$ & $-217,400$ & -3.04 & $16,590,813$ & $-125,000$ & -0.75 \\
\hline Burundi & $4,359,122$ & $-86,002$ & -1.97 & $10,124,572$ & $-20,001$ & -0.20 \\
\hline Cameroon & $9,480,638$ & $-55,000$ & -0.58 & $21,659,488$ & $-50,000$ & -0.23 \\
\hline Chad & $4,716,073$ & $-131,245$ & -2.78 & $12,715,465$ & $-120,000$ & -0.94 \\
\hline Comoros & 328,355 & $-4,500$ & -1.37 & 733,661 & $-10,000$ & -1.36 \\
\hline Cuba & $9,925,618$ & $-256,502$ & -2.58 & $11,342,631$ & $-140,000$ & -1.23 \\
\hline $\begin{array}{l}\text { Dominican } \\
\text { Republic }\end{array}$ & $6,078,816$ & $-102,692$ & -1.69 & $10,155,036$ & $-140,000$ & -1.38 \\
\hline DR Congo & $27,741,104$ & $-346,860$ & -1.25 & $70,291,160$ & $-75,000$ & -0.11 \\
\hline Fiji & 668,196 & $-11,628$ & -1.74 & 874,158 & $-28,720$ & -3.29 \\
\hline Guinea & $4,684,992$ & $-38,000$ & -0.81 & $11,628,767$ & $-10,000$ & -0.09 \\
\hline Guinea-Bissau & 885,166 & $-30,000$ & -3.39 & $1,714,620$ & $-10,000$ & -0.58 \\
\hline Haiti & $5,955,265$ & $-124,020$ & -2.08 & $10,288,828$ & $-175,001$ & -1.70 \\
\hline Jamaica & $2,200,100$ & $-81,713$ & -3.71 & $2,707,805$ & $-80,000$ & -2.95 \\
\hline Lesotho & $1,374,044$ & $-25,760$ & -1.87 & $2,057,331$ & $-19,998$ & -0.97 \\
\hline Madagascar & $9,220,693$ & $-8,000$ & -0.09 & $22,293,720$ & $-5,000$ & -0.02 \\
\hline Malawi & $6,483,571$ & $-83,786$ & -1.29 & $15,700,436$ & 0 & 0.00 \\
\hline Mali & $7,386,669$ & $-218,064$ & -2.95 & $16,112,333$ & $-302,449$ & -1.88 \\
\hline Mauritius & 992,521 & $-21,632$ & -2.18 & $1,255,882$ & 0 & 0.00 \\
\hline Mozambique & $12,511,864$ & $-373,366$ & -2.98 & $25,732,928$ & $-25,004$ & -0.10 \\
\hline Namibia & $1,056,758$ & $-29,139$ & -2.76 & $2,291,645$ & $-3,336$ & -0.15 \\
\hline Niger & $6,299,343$ & $-92,946$ & -1.48 & $17,635,782$ & $-28,497$ & -0.16 \\
\hline Nigeria & $77,729,802$ & $-671,640$ & -0.86 & $168,240,403$ & $-300,000$ & -0.18 \\
\hline Ruanda & $5,486,431$ & $-50,002$ & -0.91 & $10,817,350$ & $-44,999$ & -0.42 \\
\hline $\begin{array}{l}\text { São Tomé and } \\
\text { Principe }\end{array}$ & 98,692 & $-5,273$ & -5.34 & 178,484 & $-1,500$ & -0.84 \\
\hline Senegal & $5,888,261$ & $-85,108$ & -1.45 & $13,780,108$ & $-99,996$ & -0.73 \\
\hline Somalia & $6,271,538$ & $-832,045$ & -13.27 & $10,033,630$ & $-150,000$ & -1.49 \\
\hline Swaziland & 639,333 & $-14,496$ & -2.27 & $1,231,694$ & $-6,000$ & -0.49 \\
\hline $\begin{array}{l}\text { Trinidad and } \\
\text { Tobago }\end{array}$ & $1,120,610$ & $-34,278$ & -3.06 & $1,341,579$ & $-15,000$ & -1.12 \\
\hline Uganda & $13,318,149$ & $-115,340$ & -0.87 & $35,400,620$ & $-150,000$ & -0.42 \\
\hline Average & $8,042,278$ & $-117,641$ & -1.46 & $17,294,993$ & $-65,764$ & -0.38 \\
\hline
\end{tabular}

If we compare results from both groups (Table 1 and Table 2), we could conclude that both groups of states were able to reduce the number of migrations. The proportion of migrations in group A decreased from $4.72 \%$ in 1982 to $1.52 \%$ in 2012, and in 
Group B from $1.46 \%$ to $0.38 \%$. Nominally, countries in Group A reduced migration to a larger extent, but we have to consider the fact that in 1982 they had a larger mass of migrations. If we compare the results from both groups in 2012, we are able to conclude that states from Group A have reduced migrations by 3.1 times, and countries from Group B by 3.8 times. To conclude, greater progress was made by Group B. We can conclude that development aid has, from our point of research, no impact on international migrations in the ACP Group of States.

\section{Conclusion}

In the last 40 years much has been done, but more still has to be done to be able to understand the effects of development aid on various economic and social indicators in LDC. The basic reason for which aid is given is to generate development in order to reduce poverty (Doucouliagos and Paldam 2008), and is one of the main reason for migrations. Development aid has often been advocated as a mechanism that can reduce the development gap between destination and sending countries, and is therefore one of the best and most effective ways to reduce international migrations from LDC (Todaro and Maruszko 1987 in Gaytán-Fregoso and Lahiri 2000). In our research, we tried to prove that fact. In the context of that assumption, we tried to prove that the total amount of development aid does affect migrations abroad, and thereby if countries, which receive more of it, were able to reduce migrations in a greater way. This paper contributes to the development aid debate by focusing on a specific relation between distributed development aid and migrations abroad in the ACP Group of States.

The final results of our research are not surprising, as much research has already determined that aid has little or no effect on migrations abroad. We found that countries that received higher amounts of development aid did not reduce international migrations in a greater way than countries which received less aid. Even more, receiving countries in the ACP Group of States, with lower amounts of aid, reduced migrations by more. Thus, we can conclude that the amount of development aid has no impact on international migrations, and that its efficiency in the ACP Group of States is questionable. Conversely, we cannot neglect other factors that influence migrations, but were not part of our research. Regarding the results, we think further research is required to improve the knowledge on the impact of developmental aid policies. Sending countries should, instead of implementing restrictive, harmful policies in attempt to stop migrations, focus on a contemporary distributing system and improve it in the way that it is faster and more efficient in reducing the development gap. 


\section{REFERENCES}

Askarov, Zohid and Doucouliagos, Hristos (2015). Development Aid and Growth in Transition Countries. World Development 66, 383-399.

Belloc, Filippo (2011). International Economic Assistance and Migration: The Case of Sub-Saharian Countries. International Migrations 53(1), 187-201.

Berthélemy, Jean-Claude, Beuran Monica and Maurel Mathilde (2009). Aid and Migrations: Substitutes or Compliments. World Development 37(10), 1589-1599.

Bearce, David H. and Tirone, Daniel C. (2010). Foreign Aid Effectiveness in the Strategic Goals of Donor Governments. The Journal of Politics 72(3), 837-851. Bigsten, Arne and Tengstam, Sven (2015). International Coordination and the Effectiveness of Aid. World Development $69,75-85$.

Blodgett Bermeo, Sarah and Leblang David (2015). Migration and Foreign Aid. International Organization 69, Summer 2015, 627-657.

Boone, Peter (1996). Politics and Effectiveness of Development Aid. European Economic Review 40, 289-329.

Brech, Viktor and Potrafke, Niklas (2014). Donor Ideology and Types of Foreign Aid. Journal of Comparative Economics 42, 61-75.

Breitweiser, Anja and Wick, Katharina (2016). What We Miss By Missing Data: Aid Effectiveness Revisited. World Development 78, 554-571.

Burnside, Craig and Dollar, David (2000). Aid, Policies and Growth. The American Economic Review, 90(4), 847-868.

Carbone, Maurizio (2013). Between EU Actorness and Aid Effectiveness: The Logics of EU Aid to Sub-Saharan Africa. International Relations 27(3), 341-355.

De Haas, Hein (2005). International Migration, Remittances and Development: Myths and Facts. Third World Quarterly 26(8), 1243-1258.

Di Maria, Corrado and Lazarova Emiliya (2012). Migration, Human Capital Formation, and Growth: An Empirical Investigation. World Development 40(5), 938-955.

Doucouliagos, Hristos and Paldam, Martin (2008): Aid Effectiveness on Growth: A Meta Stud. European Journal of Political Economy 24, 1-24.

Easterly William (2007). Was Development Assistance a Mistake? The American Economic Review 97(2), 328-332.

Easterly, William in Tobias Pfutze (2008). Where Does the Money Go? Best and Worst Practices in Foreign Aid. Journal of Economic Perspective 22(2), 29-52.

Faini, Ricardo and Venturini, Alessandra (1993). Trade, Aid and Migrations: Some Basic Policy Issues. European Economic Review 37(2-3), 435-442.

Gaytán-Fregoso, Helena and Lahiri, Sajal (2000). Foreign Aid and Illegal Migration. Journal of Development Economics 63(2000), 515-527.

Glytsos, Nicholas P. (2002). The role of Migrant Remittances in Development: Evidence from Mediterranean Countries. International Migration 40(1), 5-26.

Gulrajani, Nilima (2014). Organizing for Donor Effectiveness: An Analytical Framework for Improving Aid effectiveness. Development Policy Review 32(1), 89-112.

Hansen, Henrik and Trap, Finn (2001). Aid and growth regressions. Journal of Development Economics 64(2), 547-570.

Hatzipanayotou, Panos and Michael S. Michael (2012). Migration, Foreign Aid and the Welfare State. Review of Development Economics 16(2), 199-215.

Hindman, Jennifer (2003). Aid, Conflict and Migration: The Canada-Sri Lanka Connection. The Canadian Geographer / Le Ge'ographe canadien 47(3). 251-268. 
Kandemir, Orhan (2012). Human Development and International Migration. Procedia-Social and Behavioral Sciences 62, 446-451.

Kabbanji, Lama (2013). Towards a Global Agenda on Migration and Development? Evidence from Senegal. Population, Space and Place 19, 415-429.

King, Russell, Povrzanović Frikan, Maja and Vullnetari, Julie (2013). Migration, Transnationalism and Development on the Southeastern Flank of Europe. Southeast European and Black Sea Studies 13(2), 125-140.

Kosack, Stephen (2003). Effective Aid: How Democracy Allows Development Aid to Improve the Quality of Life. World Development 31(1), 1-22.

Lacomba Joan and Boni, Alejandra (2008). The Role of Emigration in Foreign Aid Policies: The Case of Spain and Morocco. International Migration 46(1), 123-150.

Lancaster, Carol (1999). Aid Effectiveness in Africa: The Unfinished Agenda. Journal of African Economies 8(4), 487-503.

Loxley, John and Sackley, Harry A. (2008). Aid Effectiveness in Africa. African Development Review 20 (2), 163-199.

Lundsgaarde, Erik (2012). The Future of European Development Aid. Futures 44, 704-710.

Matutinović, Igor (2006). Mass Migrations, Income Inequality and Ecosystems Health in the Second Wave of a Globalization. Ecological Economics 59, 199-203.

Mallik, Girijasankar (2008). Foreign Aid and Economic Growth: A Cointegration Analysis of the Six Poorest African Countries. Economic Analysis \& Policy 38(2), 251-260.

Mergo, Teferi (2016). The Effects of International Migration on Migrant-Source Households: Evidence from Ethiopian Diversity-Visa Lottery Migrants. World Development,84, 69-81.

Nyberg-Sørensen, Ninna, Van Hear, Nicholas and Engberg-Pedersen, Poul (2002). The Migration-Development Nexus Evidence and Policy Options State-of-the-Art Overview. International Migration 40(5), 3-43.

OECD (2008). Is it ODA? Factsheet - November 2008.

Papanek, Gustav H. (1973). Aid, Foreign Private Investment, Savings and Growth in Less Developed Countries. Journal of Political Economy 81(1), 120-130.

Pecoud, Antoine and de Guchteneire, Paul (2006). International Migration, Border Controls and Human Rights: Assessing the Relevance of a Right to Mobility. Journal of Borderlands Studies 21(1), 69-86.

Rajan, Raghuram (2005). Aid and Growth: The Policy Challenge. Finance and Development 42(4), 53-55.

Stojanov, Robert and Strielkowski, Wadim (2013). The role of remittances as more efficient tool of development aid in developing countries. Prague economic papers 4, 487-503.

Todaro, Michael P. and Smith, Stephen C. (2012). Economic Development (11 $1^{\text {th }}$ edition). Boston: Pearson, Addison, Wesley.

Taufatofua, Pita (2011) Migrations, Remittance and Development. Tonga. Rome: Food and Agricultural Organization of United Nations.

Ugarte Ontiveros, Darwin and Verardi, Vincenzo (2012). Does aid induce brain drain? A panel data analysis. Journal of Migration 2012, 1-19.

Widgren, Jonas and Martin, Phillip (2002). Managing Migration: The Role of Economic Instruments. International Migration 40(5), 213-226.

Ziesmer, Thomas (2011). Growth with endogenous migration hump and the multiple, dynamically interacting effects of aid in poor developing countries. Applied Economics 43, 4865-4878.

Zimelis, Andris (2011). Conditionality and the EU-ACP Partnership: A Misguided Approach to Development? Australian Journal of Political Science 46(3), 389-406. 


\section{NOTES}

1 Somalia did sign the agreement, but did not ratify it.

2 Antigua and Barbuda, Bahamas, Barbados, Belize, Cuba, Dominica, Dominican Republic, Grenada, Guyana, Haiti, Jamaica, St. Lucia, St Vincent and the Grenadines, St Kitts and Nevis, Suriname, Trinidad and Tobago.

3 Benin, Burkina Faso, Cape Verde, Cote d'Ivoire, Gambia, Ghana, Guinea, Guinea-Bissau, Liberia, Mali, Mauritania, Niger, Nigeria, Senegal, Sierra Leone, and Togo.

4 Cameroon, Central African Republic, Chad, Congo (Brazzaville), Congo - Democratic Republic of (Kinshasa), Equatorial Guinea, Gabon, São Tomé and Principe.

5 Comoros, Djibouti, Eritrea, Ethiopia, Madagascar, Malawi, Mauritius, Seychelles, Somalia, Sudan, Zambia, and Zimbabwe.

6 Burundi, Kenya, Rwanda, Tanzania, and Uganda,

7 Angola, Botswana, Lesotho, Mozambique, Namibia, South Africa, and Swaziland.

8 Cook Islands, Fiji, Kiribati, Marshall Islands, Micronesia, Federated States of, Nauru, Niue, Palau, Papua New Guinea, Samoa American, Samoa Western, Solomon Islands, Tonga, Tuvalu, and Vanuatu.

9 Population growth in the same time period in Europe was $6.5 \%$. 